This is not the final manuscript - it is an Author's Accepted Manuscript of a book contribution. Full citation: Lemke, T. (2019). Going Further: Lebensformen, Politics, and Critique. In: Graw, I. \& Menke,

C. (Hg.), The Value of Critique. Exploring the Interrelations of Value, Critique, and Artistic Labour, Frankfurt am Main/ New York, 120-125.

\title{
Going Further: Lebensformen, Politics and Critique
}

\begin{abstract}
"We have to start all again right from the beginning, and ask ourselves on what we can base the critique of our society" (Foucault 1994: 398; translation by TL)
\end{abstract}

Rahel Jaeggi's work has significantly shaped contemporary projects in revising and updating critical theory (Jaeggi 2014; 2015). The theoretical and political debate that enfolded around her writings focusses on the concept of a critique of forms of life ("Lebensformen"). It is characterized by several important conceptual innovations.

First, against persistent claims about and calls for the end of critique, Jaeggi convincingly argues that critique is not something we can abandon or avoid. On the contrary, practices of justification and normative questions constitute and transform what she calls forms of life. She understands these as modes of posing and solving problems. In this sense, we are always already engaged in critique (Jaeggi 2015: 13). Secondly, Jaeggi also extends the terrain of critique by opening up the continent of Lebensformen to confrontation and normative evaluation. Critique is not only an essential and inescapable fact of social relations. Forms of life are also bound up with practices of justification and critique - practices that rely on a multitude of values and normative orientations that are neither isolated nor impenetrable (Celikates 2015). Thirdly, Jaeggi understands critique in procedural and practical terms. She elaborates what she calls "a practice theoretical account of forms of life" (Jaeggi 2015: 15) that focuses on problems and is attuned to experiences of crisis. Fourthly, Jaeggi makes a strong argument for immanent critique: a form of critique that can be distinguished from internal or external modes of critique. Both are characterized by a number of serious weaknesses and difficulties which her work convincingly exposes (Jaeggi 2014).

As I pointed out in an article some years ago, there is a certain degree of parallelism between this idea of a critique of forms of life and Michel Foucault's ethos of critique 
(Lemke 2011). In fact, Foucault occasionally uses the term "forms of life" himself. Yet, the more important point is that in all of his work from the 1970s onwards he advocated the idea that forms of life are open to critique and change as that they cannot be dissociated from power relations. From the notion of government as a way of living

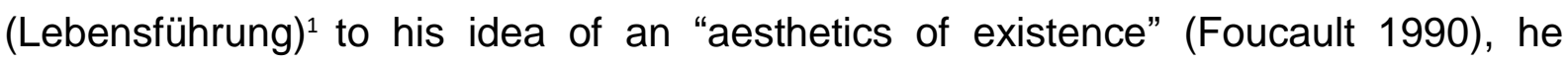
permanently stressed the political dimensions of forms of life, subverting the lines of division between politics and ethics, the individual and the collective, the private and the public.

This is not the place to elaborate this point in any depth (see for a more comprehensive discussion: Lemke 1997). Let me just briefly illustrate this argument with Foucault's understanding of a "gay form of life". In the History of Sexuality Foucault reconstructed the historical process by which sexual practices came to be regarded as central for personal identity. Thus, he thought that those struggles for liberation which claim a right to one's sexuality are limited if they accept the idea of a "true sex"一an idea promoted by institutions seeking to control and regulate sexuality. Foucault wanted to distance himself from this idea of a "true sexuality" in order to allow new forms of sexual experience. However, it does not follow from this that he rejected the notion of identity or the recourse to rights. According to Foucault, a gay form of life does not replace the struggle for rights and sexual self-determination. On the contrary, he insisted on the importance of legal rights. In this sense this was not a matter of 'either/or', nor was there any contradiction between the two strategies. Rather, Foucault stressed that any movement has to go beyond demanding rights and sexual tolerance to develop new forms of life:

„It is important, first, to have the possibility - and the right - to choose your own sexuality. Human rights regarding sexuality are important and are still not respected in many places. [...]. Still, I think we have to go a step further. I think that one of the factors of this stabilisation will be the creation of new forms of life, relationships, friendships in society, art, culture, and so on through our sexual, ethical, and political choices. Not only do we have to defend ourselves, not only affirm ourselves as an identity but as a creative force." (Foucault 1997: 164)

\footnotetext{
${ }^{1}$ Colin Gordon and Pasquale Pasquino have pointed out that Foucault's definition of ethics as 'conduct' parallels Max Weber's concept of Lebensführung (Gordon 1986a: 83-5; 1986b; Pasquino 1986: 99-100).
} 
Foucault's emphasis on the creative and transformative dynamics of forms of life is intimately tied to a theoretical re-evaluation of 'experience' - and again let me stress the similarities to Jaeggi's project. Like forms of life that, as she points out in her work, link the past and the future, the stable and the malleable, experience in Foucault's terms comprises two seemingly contradictory dimensions (see Lemke 2011). He conceives experience as a dominant structure and transformative force, as an existing background of practices and a transcending event, the object of theoretical inquiry and the objective of moving beyond historical limits. Note the double meaning of expérience in French as both 'experiment' and 'experience'. Jaeggi takes up this understanding when she conceives of forms of life as "experiments" and advocates an "experimental pluralism of forms of life" (2014: 451).

So far, I have stressed the parallels and similarities between Foucault's work and Jaeggi's proposal of a critique of forms of life. In the following, I will mark some differences in their projects. I will remain faithful to Jaeggi's proposal and engage in an immanent critique of her idea of critique by focusing on two main ingredients of the menu: "forms of life" and "critique".

The German notion of Lebensform comprises and binds together two different meanings that in English allow for alternative terms: "life forms" and "forms of life". While the former relates to biological entities like organisms and species, the latter addresses social and symbolic practices that organize human collectives (see Helmreich 2011: 673; Helmreich and Roosth 2010). The biological meaning came first, originating in the first half of the 19th century. Yet from the $20^{\text {th }}$ century on, the social understanding is the one mostly used in philosophy and social theory. Accordingly, in Jaeggi's work Lebensformen are conceived of as cultural entities (Jaeggi 2014: 20; 2015: 16). As she rightly stresses the importance of a materialist account of critique (see e.g. 2015: 18), we need to extend this cultural understanding to encompass this material and bodily dimension of Lebensformen. To conceive of Lebensformen as cultural entities only tends to reflect and restage a rather limited and historically specific understanding of Lebensform that we might call "modern". It ignores the semantic richness of the notion and neatly separates the natural from the cultural - as Bruno Latour and many others have pointed out (Latour 1993). The interesting point about "Lebensform" is that the term transgresses the boundaries of the social and the human as it addresses "naturecultures", in Donna Haraway's terminology (2003). By limiting 
forms of life to their cultural dimensions, a duality of the social and the biological, the human and the non-human is reinscribed.

It is necessary to propose a broader and more comprehensive understanding of Lebensform that endorses a weak and fluid concept of humanity-a concept of humanity that is highly dependent on and embedded in non-human nature. Instead of celebrating human uniqueness and singularity, the analytical privilege is transferred to multiple connections, heterogeneous inter-actions, and associations of humans with the non-human. ${ }^{2}$ This conceptual extension of Lebensform makes it possible to address critically the environmental challenges of the Anthropocene and the social capacity of contemporary techno-sciences to transform or enhance human and nonhuman bodies. Thus, it brings up the question of who gets to decide what forms of life will be lived on Earth, under what conditions-and what forms of life will become biologically but also socially extinct (Dalby 2013).

The conceptual revision of "forms of life" needs to be complemented by a more comprehensive understanding of critique. While Jaeggi makes a powerful argument for the idea of immanent critique, there are some difficulties to be noted in her account. As forms of life are conceived as instances of problem-solving (2014: 200), there is a risk of understanding critique as some kind of technical procedure or measurement process that addresses solutions to problems in terms of how good and adequate or deficient and inadequate they are. The perspective of an immanent critique rightly distances itself from an "authoritarian external perspective" (2015: 26). However, the procedural turn to a normative position that abstains from normativity still leaves some questions open. What exactly is a good or adequate solution? And is it not precisely what counts as good or adequate that is contested in critical practices? Also: how do we detect a "good theory"? (see Jaeggi 2014: 278). Thus, there is a risk that the fleshly, lively, bodily side of forms of life does not get enough critical attention. We not only

\footnotetext{
2 See e.g. Haraway's concept of "companion species": "I love the fact that human genomes can be found in only about 10 percent of all the cells that occupy the mundane space I call my body; the other 90 percent of the cells are filled with the genomes of bacteria, fungi, protists, and such, some of which play in a symphony necessary to my being alive at all, and some of which are hitching a ride and doing the rest of me, of us, no harm. I am vastly outnumbered by my tiny companions; better put, I become an adult human being in company with these tiny messmates. To be one is always to become with many. Some of these personal microscopic biota are dangerous to the me who is writing this sentence; they are held in check for now by the measures of the coordinated symphony of all the others, human cells and not, that make the conscious me possible. I love that when 'l' die, all these benign and dangerous symbionts will take over and use whatever is left of 'my' body, if only for a while, since 'we' are necessary to one another in real time." (Haraway 2008: 3-4; emphasis in orig.)
} 
inhabit forms of life but are informed and deformed by them, and they account for who this "we" is. The intention to avoid a normatively loaded concept of critique and to focus on the functional capacities of problem-solving might end up in a technical and procedural understanding of forms of life that tends to ignore or downplay not only the affective dimensions of forms of life but also their political character: the confrontational, hegemonic and transgressive character of many forms of life (Schäfer 2015; Loick 2016). Rather than endorsing an "experimental pluralism of forms of life" (Jaeggi 2014: 451) that exist alongside each other, isolated or separated from one another, it seems more pertinent to emphasize their political and agonistic character. The two propositions advanced in this paper seek to strengthen the project of a critique of forms of life. They share the interest to shift the register of critique from "ethical abstinence" (see Jaeggi 2015: 14) to a pragmatic investigation that examines how specific forms of life operate. Jaeggi's work has convincingly shown how to avoid the pitfalls of internal and external critique, it has brought the notion of Lebensform to the fore, and has opened up a new domain and an alternative procedure of critique. Now we need to go one step further. To remain faithful to the idea of an immanent and experimental style of critique means that we have to come up with a more than cultural understanding of Lebensform; we need to explore a more agonistic concept of critique. This is perhaps the most important achievement and appeal of Jaeggi's proposal of an immanent critique: to conceive of critique as a dynamic force in terms of transformation and change and as a learning process - a critical capacity that extends to the notion of critique itself.

\section{Literature}

Celikates, R. (2015). Against Manichaeism: The Politics of Forms of Life and the Possibilities of Critique. Raisons politiques, 57(1), 81-96.

Dalby, S. (2013). Biopolitics and Climate Security in the Anthropocene. Geoforum, 49, 184192.

Foucault, M. (1990). The History of Sexuality: The Use of Pleasure (Vol. 2). New York: Vintage.

Foucault, M. (1994). La torture, c'est la raison. In M. Foucault, Dits et Ecrits (Vol. 3, pp. 390398). Paris: Gallimard.

Foucault, M. (1997). Sex, Power, and the Politics of Identity. In M. Foucault, R. Hurley, P. Rabinow, \& J. D. Faubion, Ethics, Subjectivity and Truth. Essential Works of Michel Foucault (pp. 163-173). New York: The New Press.

Gordon, C. (1986a). Question, Ethos, Event: Foucault on Kant. Economy \& Society, 15(1), $71-87$.

Gordon, C. (1986b). Foucault en Angleterre. Critique, 471/472, 826-839. 
Haraway, D. (2003). The Companion Species Manifesto: Dogs, People, and Significant Otherness. Chicago: Prickly Paradigm Press.

Haraway, D. (2008). When Species Meet. Minneapolis: University of Minnesota Press.

Helmreich, S. (2011). What Was Life? Answers from Three Limit Biologies. Critical Inquiry, 37(4), 671-696.

Helmreich, S., \& Roosth, S. (2010). Life Forms: A Keyword Entry. Representations, 112, $27-$ 53.

Jaeggi, R. (2014). Kritik von Lebensformen. Berlin: Suhrkamp.

Jaeggi, R. (2015). Towards an Immanent Critique of Forms of Life. Raisons politiques, 57(1), 13-29.

Latour, B. (1993). We have never been modern. Cambridge: Harvard University Press.

Lemke, T. (1997). Eine Kritik der politischen Vernunft. Foucaults Analyse der modernen Gouvernementalität, Berlin und Hamburg: Argument.

Lemke, T. (2011). Critique and Experience in Foucault. Theory, Culture \& Society, 28(4), 26-48.

Loick, D. (2016). Zur Kritik von Lebensformen. WestEnd. Neue Zeitschrift für Sozialforschung, 2, 149-162.

Pasquino, P. (1986). Michael Foucault (1926-84): The Will to Knowledge. Economy and Society, 15(1), 97-109.

Schäfer, H. (2015). Besprechung von Rahel Jaeggi, Zur Kritik von Lebensformen. Soziologische Revue, 38(4), 581-585. 